\title{
PARTIAL CHARACTERIZATION OF AMYLASE ENZYME FROM NEWLY ISOLATED BACTERIAL STRAIN FROM GARDEN SOIL
}

\author{
ABHISHEK ${ }^{1}$, VISHAL $^{2}$, MANPREET $^{3}$, NAVNEET BATRA ${ }^{4}$ \& MEENU WALIA $^{5}$ \\ ${ }^{1,2,3}$ Department of Biotechnology, SD College, Ambala Cantt., India \\ ${ }^{4}$ Department of Biotechnology, GGDSD College, Chandigarh, India \\ ${ }^{5}$ Assistant Professor, Department of Biotechnology, SD College, Ambala Cantt., India
}

ABSTRACT
Amylase producing bacterial strain MB2 was isolated from soil and it showed maximum production of enzyme in 48
hours. Crude enzyme has an optimum temperature of $40^{\circ} \mathrm{C}$ and optimum $\mathrm{pH}$ of 7.0 . The relative enzyme activity of $97 \%$
was observed at pH 6. After incubation for $400 \mathrm{C}$, the enzyme lost only $2.5 \%$ of activity after 48 hours of incubation.
More than $90 \%$ of activity were retained even after 48 hours at $\mathrm{pH} 7$. Calcium acts as an activator for amylase.
KEYWORDS: Amylase, Stability, Starch Hydrolysis, Optimum $\mathrm{pH} \&$ Calcium

Received: Jun 09, 2017; Accepted: Jul 04, 2017; Published: Jul 10, 2017; Paper Id.: IJBTRAUG20172

\section{INTRODUCTION}

Amylase is an industrially important enzyme, which break down starch into maltose and dextrins, which further finally degraded into glucose units. Due to the commercial application of amylase enzyme in paper industry, induction of sugar from production of sugar syrup, fabrics decision, liquefaction of starch, brewing industry, pharmaceuticals is essentially important for industrial purpose (Ito et al., 1998; Ammar et al., 2002; Xie et al., 2014). Application of $\alpha$-amylase for fiber splitting in leather processing was reported by Pandi et al., (2016). The main source of amylase enzyme are plants, animals and microorganisms. Mainly, microorganisms are used for amylase production. Because of their stability at extreme conditions, biochemical versatility, the production rate is higher and large scale availability of microbial strains in a short time is possible at low cost production.

Amylase is also known as glycoside hydrolases as it acts on $\alpha 1,4$ glycosidic bond. They are highly specific for substrate. Alpha and beta are the main subtypes of amylase enzyme. Alpha amylase is faster acting enzyme as compared to beta amylase. Endoamylase and exoamylase are two categories of enzyme. Endoamylase enzyme led to the formation of linear and branched chain oligosaccharides by catalyzing hydrolysis in a random manner within the starch molecule. However, exoamylases produces shorter end products by hydrolyzing from the nonreducing end. Amylose and amylopectin are two glucose polymers which are connected by glycosidic bond and ultimately led to the formation of the starch molecule. Amylose is a linear polymer which consists of 6000 glucose units that are joined by $\alpha-1,4$ glycosidic bond, while amylopectin consists of 10-60 glucose units which are linked by $\alpha-1,4$ glycosidic bond by $15-45$ glucose units having $\alpha-1,6$ linked side chains. To maintain their structural conformation, stability and activity amylase enzyme require calcium ion.

Amylase enzyme isolated from bacteria, fungi and yeast have been used in scientific research and in 
industrial area on a priority basis (Ali et al., 2014; Kaur et al., 2017). Production of enzyme level varies from one microbial organism to another organism. The environment from which strains have isolated plays a significant role in enzyme production rate. That is, strains isolated from starch rich or amylase rich zone had a comparatively higher amount of enzyme. Similarly, environmental factors like temperature, $\mathrm{pH}$, carbon and nitrogen sources, salt concentration, and metallic ions also played a vital role in producing an enzyme.

Out of different microbes, which are used as a source for production of amylase enzyme, the bacteria used predominantly for enzyme production as it is cheaper and faster than from other microbial species. Bacteria are also feasible for the recombination purpose as manipulation can be easily done with bacteria. A wide range of strains has been isolated and screened for amylase production from different environments. Bacillus is the strain which is most commonly isolated. However, Corynebcaterium, Rhodothermus, Lactobacillus, Pseudomonas also comes under the category of amylase enzyme production.

\section{MATERIALS AND METHODS}

\section{Isolation and Screening of Strain}

Soil sample was diluted and spread plated on medium plates containing nutrient agar media containing $1 \%$ starch. After $24 \mathrm{hrs}$ of incubation Petri plate were taken out and iodine was added to the plate zone of clearance occurs around the strain showing positive results after adding iodine. Depending upon the diameter of the zone of clearance stain MB2 was selected for further isolation and characterization of the enzyme

\section{Growth of MB2 for Enzyme Production}

MB2 strain was grown in nutrient broth containing $1 \%$ of the starch and incubate at $37^{\circ} \mathrm{C}, 150 \mathrm{RPM}$. After different interval, took out a flask, and transfer $1.5 \mathrm{ml}$ of culture in a microfuge tube. Followed by centrifugation at 8000 rpm for 15 mins. Separated out the supernatant and discard the pellet. The supernatant contained crude enzyme.

\section{Enzyme Assay}

The enzyme activity was studied by following the technique of Shaw et al. (1995) with certain modifications. Assay mixture $(500 \mu \mathrm{L})$ having $250 \mu \mathrm{L}$ of starch $(1 \%)$ in $0.2 \mathrm{M}$ sodium phosphate buffer of appropriate $\mathrm{pH}$ and $50 \mu \mathrm{L}$ of appropriately diluted enzyme was incubated at $40^{\circ} \mathrm{C}$ for $10 \mathrm{~min}$. After incubation, $750 \mu \mathrm{L}$ of DNS reagent was added and the mixture was boiled for $10 \mathrm{~min}$ followed by the addition of $1.25 \mathrm{ml}$ of distilled water. The absorbance was read at 540 NM in spectrophotometer with appropriate substrate and enzyme blank. Glucose was used as standard. One unit (U) of $\alpha-$ amylase is described as amount, which produces $1 \mathrm{mmol}$ of glucose per $\mathrm{mL}$ per min.

\section{Characterization of Amylase}

\section{Effect of Incubation Temperature on Amylase Activity}

The effect of temperature on amylase was measured in the range of 30 to $80^{\circ} \mathrm{C}$. The reaction mixture was incubated for $10 \mathrm{~min}$ at different temperatures and the residual activity was determined.

\section{Effect of pH on Amylase Activity}

The effect of $\mathrm{pH}$ from 4.0 to 10.0 on the amylase activities was measured in $0.2 \mathrm{M}$ citrate buffer (pH $4-5$ ), $0.2 \mathrm{M}$ sodium phosphate buffer ( $\mathrm{pH} 6-8)$ and $0.2 \mathrm{M}$ glycine- $\mathrm{NaOH}$ buffer ( $\mathrm{pH} 9$ - 10). The relative amylase activity was determined after carrying out the reactions in different $\mathrm{pH}$. 


\section{Thermal Stability of enzyme}

To estimate the thermal stability, the appropriate dilution of the enzyme was made in $0.2 \mathrm{M}$ phosphate buffer ( $\mathrm{pH}$ 7.0) and incubated at $40^{\circ} \mathrm{C}$ and $50^{\circ} \mathrm{C}$. Samples were with-drawn at different intervals of time and immediately placed in ice before measuring amylase activity.

\section{pH Stability of Enzyme}

To determine the stability at different $\mathrm{pH}$, the enzyme was incubated for $12 / 24 \mathrm{~h}$ at different $\mathrm{pH}$ values before the residual activity was determined at $\mathrm{pH} 7.0$

\section{The effect of Cations/Inhibitors/Activators on Amylase Activity}

Cations/activators/inhibitors (final concentration $5 \mathrm{mM}$ ) were added to a reaction medium. The enzyme activity was assayed under standard conditions and inhibition/activation was expressed as a percentage of the activity of control (without the effectors).

\section{RESULTS AND DISCUSSIONS}

From our work, different strains showed positive result of amylase production, but one strain MB2 shows larger zone of clearance. Hence MB2 bacterial strain (Figure 1) is chosen for the study of amylase. Figure 2 represents the growth profile of the selected strain. Growth and crude enzyme activity was observed at different interval of time. Upto 6 hours there was little growth, which is associated with slight extracellular enzyme production. With increase in time of incubation, the biomass and amylase production increased. After 24 hours of growth, enzyme activity of $145.5 \mathrm{U} / \mathrm{ml}$ was obtained. Maximum enzyme production of $350 \mathrm{U} / \mathrm{ml}$ was observed corresponding to an OD of 1.35 after 48 hours of growth. Crude enzyme was prepared after centrifugation of culture after 48 hours and the supernatant was used for further characterization of the enzyme.

Effect of incubation temperature was checked for temperature $30-80^{\circ} \mathrm{C}$ (Figure 3). Minimum activity was observed at $30^{\circ} \mathrm{C}$. As the temperature increased to $40^{\circ} \mathrm{C}$, more than $30 \%$ of activity was increased. However, with further increases to $45^{\circ} \mathrm{C}$, there is a slight decrease $(2 \%)$ in activity. There is a steep decrease in activity as temperature increased towards $80^{\circ} \mathrm{C}$. Almost negligible activity was observed at $80^{\circ} \mathrm{C}$ due to loss in active structure or denaturation of enzymes. In earlier studies reported by Behal et al., (2006), the activity of AB $04 \alpha$-amylase was showed activity between 40 and $80^{\circ}$ $\mathrm{C}$ and the optimum activity was at $40^{\circ} \mathrm{C}$ with more than $70 \%$ activity is observed up to $80^{\circ} \mathrm{C}$ at $\mathrm{pH} 8$.

Effect of $\mathrm{pH}$ on crude amylase shows less activity at lower and higher $\mathrm{pH}$. Maximum activity was observed at $\mathrm{pH}$ 7.0 while $98 \%$ and $85 \%$ relative activity was observed at pH 6 and pH 8 respectively (Figure 4). Wide variation in optimum $\mathrm{pH}$ in amylases isolated from various sources has been reported in the literature as per source of the sample.

Figure 5 represents the effect of incubation temperature on activity of the crude amylase enzyme obtained from strain MB2. The enzyme was completely stable up to 36 hours at $4^{\circ} \mathrm{C}$. At a temperature of $40^{\circ} \mathrm{C}$, the enzyme showed stability and had relative activity of $98.2 \%$ and $97.5 \%$ after 24 hours and 36 hours respectively. In previous studies of AB04 strain, more than $94 \%$ activity was retained even after $5 \mathrm{~h}$ of incubation at $40^{\circ} \mathrm{C}$ (Behal et al., 2006). The optimal performance of the detergents requires amylase with optimum temperature $40-60^{\circ} \mathrm{C}$ (Bisgaard-Frantzenet al., 1999).

The enzyme from MB2 strain variable activity in the presence of various metal ions as shown in Table $1 . \mathrm{Ca}^{+2}$ increased the activity more than $55 \%$, while $\mathrm{Cu}^{+2}$ acted as an inhibitor. Thus the maximum enzyme produced by the 
bacterial strain MB2 in 48 hours showed an optimum temperature of $40^{\circ} \mathrm{C}, \mathrm{pH}$ optimum of 7 , good temperature stability and $\mathrm{pH}$ stability and activation a with $\mathrm{Ca}^{+2}$ is showing maximum activity at $\mathrm{pH} 6$ and $50^{\circ} \mathrm{C}$ temperature making it suitable for various industrial processes.

\section{REFERENCES}

1. Ammar, Y. B., T. Matsubara., K. Ito., M. Iizuka., T. Limpaseni., P. Pongsawasdi., and N. Minamiura., (2002). New action pattern of a maltose-forming alpha-amylase from Streptomyces sp. and It is possible application in bakery. J. Biochem., Mol. Biol., 35: 568-575.

2. Behal, A., Singh J, Puri, P. and Batra, N. (2006). Characterization of alkaline alpha amylase from bacillus sp. AB04. Int. J Agri. Biol. 8: 80-83.

3. Bisgaard-Frantzen, H., A. Svendsen., B. Norman., S. Pedersen., S. Kjarulf., H. outtrup., and T. V. Borchert., (1999). Development of industrially important $\alpha$-amylases. J. Appl. Glycosci., 46: 199-206

4. Ito, S., T. Kobayashi., K. Ara., K. Ozak.i, S. Kawai., and Y. Hatada., 1998. Alkaline detergent enzymes from alkaliphiles: enzymatic properties, genetics, and structures. Extremophiles., 2: 185-90

5. Xie, F., Quan, S., Liu, D., Ma, H., Li, F., Zhou, F., and Chen, G. (2014). Purification and characterization of a novel $\alpha$ amylase from a newly isolated Bacillus methylotrophicus strain P11-2. Process Biochemistry, 49(1), 47-53.

6. Kaur, A., Kaur, M., Samyal, M. L., and Ahmed, Z. (2017). Isolation, characterization and identification of bacterial strain producing amylase. Journal of Microbiology and Biotechnology Research, 2(4), 573-579.

7. Ali, I., Akbar, A., Yanwisetpakdee, B., Prasongsuk, S., Lotrakul, P and Punnapayak, H. (2014). Purification, characterization, and potential of saline waste water remediation of a polyextremophilic $\alpha$-amylase from an obligate halophilic Aspergillus gracilis. BioMed research international, 2014.

8. Pandi, A., Ramalingam, S., Rao, J. R., Kamini, N. R., \& Gowthaman, M. K. (2016). Inexpensive $\alpha$-amylase production and application for fiber splitting in leather processing. RSC Advances, 6(39), 33170-33176.

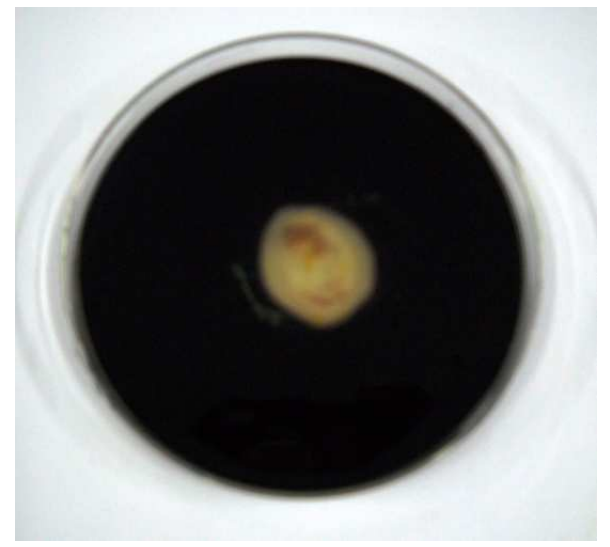

Figure 1: Zone of Clearance Observed on Iodine Staining 


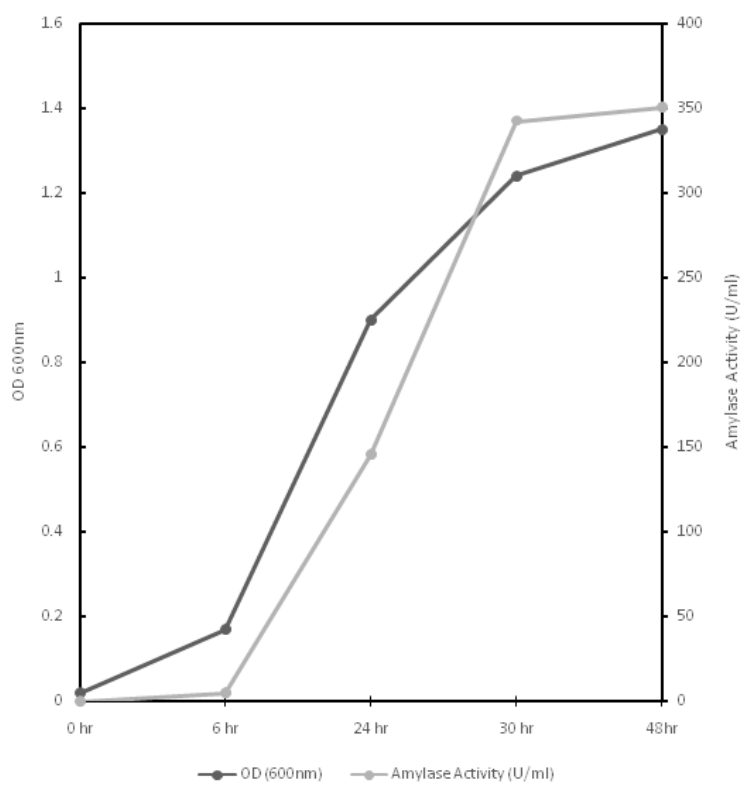

Figure 2: Growth and Enzyme Production Profile of MB2 Strain

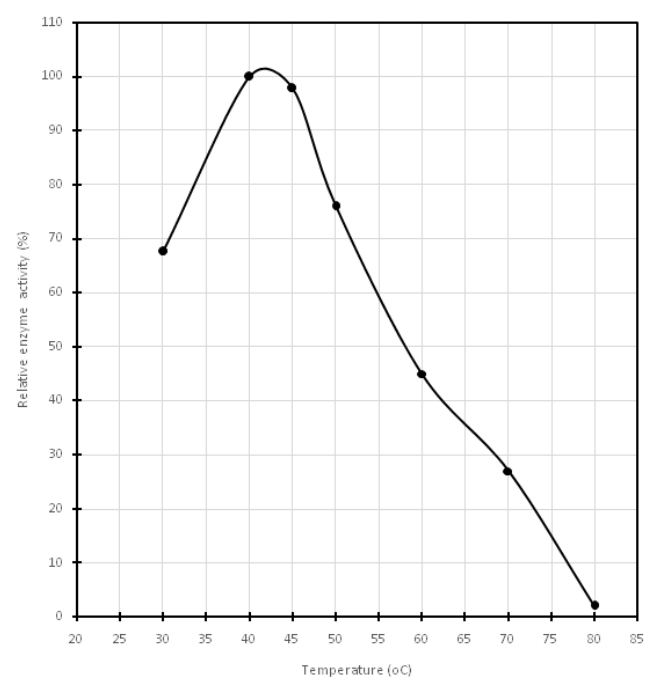

Figure 3: Effect of Incubation Temperature on Amylase Activity 


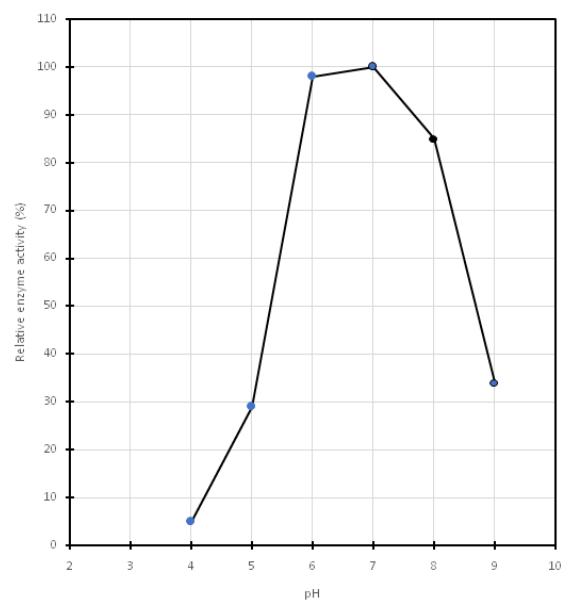

Figure 4: Effect of pH on Amylase Activity

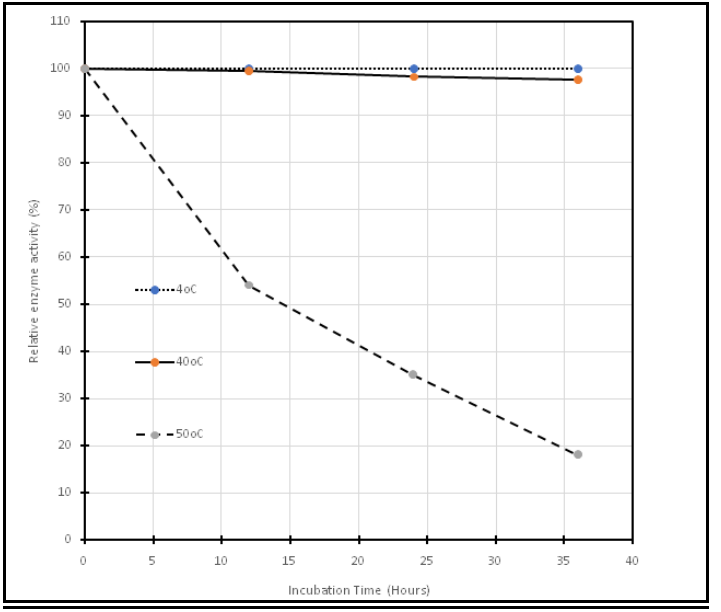

Figure 5: Effect of Incubation Temperature on Stability of Amylase Activity 


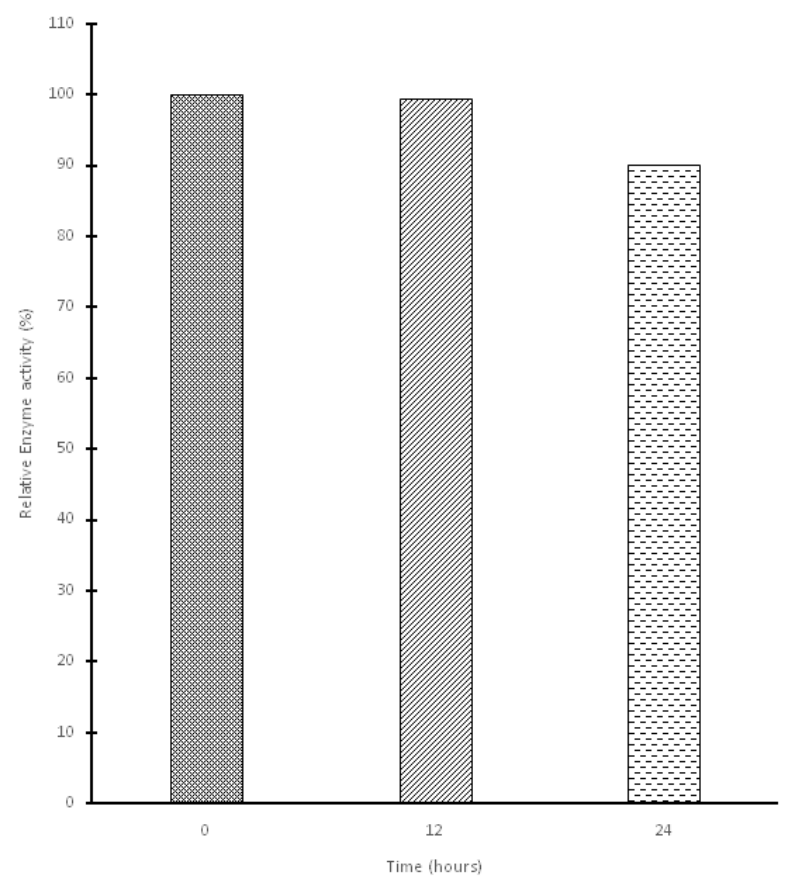

Figure 6: Stability of Amylase Activity at pH 7

Table 1: Effect of Various Metal Ions on Enzyme Activity

\begin{tabular}{|l|c|}
\hline Metal Ion & Relative Activity (\%) \\
\hline Control & 100.00 \\
\hline $\mathrm{Na}^{+}$ & 98.75 \\
\hline $\mathrm{Mg}^{+2}$ & 99.56 \\
\hline $\mathrm{Fe}^{+2}$ & 85.67 \\
\hline $\mathrm{Ca}^{+2}$ & 156.45 \\
\hline $\mathrm{Mg}^{+2}$ & 102.12 \\
\hline $\mathrm{Cu}^{+2}$ & 35.67 \\
\hline
\end{tabular}


